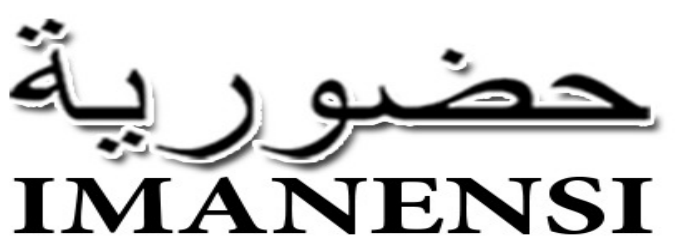

Jurnal Ekonomi, Manajemen, dan Akuntansi Islam

Vol 5, No 2, September 2020, H1mn. 79-92

\title{
Pemahaman perpajakan, kesadaran pajak dan tingkat pendapatan sebagai determinan kepatuhan pajak UMKM
}

\section{Hari Setyo Widodo a, $1, *$ Dian Purnama Sari ${ }^{\mathrm{b}, 2}$}

abSekolah Pascasarjana Universitas Katolik Widya Mandala Surabaya, Graha Widya Mandala Jl. Dinoyo 48A Surabaya 60265. Indonesia. 1.Hariwdd02@yahoo.com* 2dian-ps@ukwms.ac.id

* correspondence author

10.34202/imanensi.5.2.2020.79-92.

\begin{abstract}
Abstrak
Tujuan dari penelitian ini adalah untuk mengetahui pemahaman peraturan perpajakan, kesadaran membayar pajak dan tingkat pendapatan UMKM berpengaruh terhadap kepatuhan wajib pajak UMKM. Jenis penelitian kuantitatif dan sumber data diperoleh dari kuesioner yang dibagikan langsung kepada pemilik UMKM. Regresi linier berganda digunakan sebagai metode analisis data. Hasil analisis data disimpulkan bahwa pemahaman peraturan perpajakan dan tingkat pendapatan UMKM berpengaruh terhadap kepatuhan wajib pajak UMKM. Untuk kesadaran membayar pajak tidak berpengaruh terhadap kepatuhan wajib pajak UMKM. Hal ini dapat diartikan bahwa meskipun pelaku usaha mau membayar pajak namun belum dapat meningkatkan kepatuhan perpajakannya.
\end{abstract}

Kata kunci: Kepatuhan Pajak; Pemahaman Perpajakan; Kesadaran Pajak; Tingkat Pendapatan.

\begin{abstract}
The purpose of this study was to determine the understanding of tax regulations, the awareness of paying taxes and the level of income of MSMEs that affect the compliance of MSME taxpayers. This type of quantitative research and data sources were obtained from questionnaires that were distributed directly to MSME owners. Multiple linear regression was used as a method of data analysis. The results of data analysis concluded that the understanding of tax regulations and the level of income of MSMEs had an effect on the compliance of MSME taxpayers. The awareness of paying taxes does not affect the compliance of MSME taxpayers. This may imply that even though business actors are willing to pay taxes, they have not been able to improve their tax compliance.
\end{abstract}




\section{PENDAHULUAN}

Kepatuhan pajak memiliki arti sebagai pemenuhan kewajiban perpajakan oleh wajib pajak dalam bentuk kepatuhan formal dan kepatuhan material (Nurmantu, 2005:148). Kepatuhan formal yaitu suatu keadaan dimana wajib pajak telah menjalankan aturan perpajakan serta kewajibannya sesuai ketentuan pajak. Sedangkan kepatuhan material yaitu wajib pajak telah melaksanakan perpajakannya serta kewajibannya berdasarkan substantif atau secara material pajaknya, seperti membayar dan melaporkan SPT dengan benar dan lengkap (Nurmantu, 2005:148). Kriteria kepatuhan wajib pajak seperti yang tertuang dalam Peraturan Menteri Keuangan Nomor 74/PMK.03/2012 adalah pelaporan SPT sesuai dengan waktu yang telah ditetapkan, tidak memiliki tunggakan pajak untuk semua jenis pajak, kecuali yang mendapat ijin untuk ditunda pembayarannya, selama tiga tahun terakhir mendapat opini wajar tanpa pengecualian dalam laporan keuangannya dan selama lima tahun terakhir belum pernah dipidana terkait perpajakan berdasarkan keputusan pengadilan yang telah memiliki kekuatan hukum tetap.

Membangun kesukarelaan dan kesadaran membayar pajak bukanlah perkara yang mudah. Berdasarkan penelitian yang dilakukan oleh Yusro dan Kiswanto (2014) masalah kepatuhan pajak yang terus terjadi disebabkan oleh rendahnya kepatuhan perpajakan wajib pajak. Disisi lain peningkatan usaha di Indonesia belum seimbang dengan kepatuhan perpajakannya. Tiap tahunnya UMKM terus tumbuh akan tetapi tidak diikuti kepatuhan perpajakannya (Yusro dan Kiswanto, 2014). Penelitian ini didukung oleh beberapa penelitian sebelumnya, diantaranya yaitu Fahluzy dan Agustina (2014) menyimpulkan bahwa pemahaman tentang peraturan perpajakan berpengaruh terhadap kepatuhan UMKM. Penelitian oleh Mahfud (2016) hasilnya adalah pemahaman peraturan perpajakan berpengaruh terhadap kepatuhan wajib pajak badan. Kemudian penelitian Riyantono (2017), Kalsum (2015) dan Imaniati (2016) menyatakan bahwa pemahaman peraturan perpajakan berpengaruh terhadap kepatuhan wajib pajak UMKM.

Merujuk dari penelitian Fauzi (2016) kesadaran membayar pajak merupakan faktor yang dapat mempengaruhi kepatuhan wajib pajak. Hasil penelitian yang sama juga dilakukan oleh Zulaikha (2012), Sasmita (2015) dan Kalsum (2016) yang menyatakan bahwa kesadaran membayar pajak memiliki pengaruh terhadap kepatuhan wajib pajak UMKM. Kemudian penelitian yang dilakukan oleh Yusro dan Kiswanto (2014) menyimpulkan kesadaran membayar pajak tidak berpengaruh terhadap kepatuhan wajib pajak. Seperti diketahui di Indonesia menggunakan self assessment system oleh sebab itu kuncinya adalah kesadaran membayar pajak dalam memaksimalkan penerimaan pajak, karena self assessment system memberi kepercayaan secara sukarela (voluntary tax compliance) untuk melakukan kewajiban perpajakannya berdasarkan ketentuan yang berlaku. Berdasarkan dari hasil penelitian yang berbeda-beda atau biasa disebut dengan research gap merupakan dasar dari penulis untuk melakukan penelitian.

Acuan yang digunakan oleh penulis adalah penelitian yang relevan pada periode sebelumnya dengan fenomena dan topik yang hampir serupa memperlihatkan hubungan atau hasil yang berbeda-beda. Namun perbedaan dengan penelitian yang relevan ialah terletak pada variabel bebasnya yaitu tingkat pendapatan UMKM dan lokasi penelitian dalam pengambilan sampelnya. Penulis tertarik untuk melakukan penelitian karena pajak sebagai 
penyumbang terbesar bagi APBN, ada sekitar 70\% didanai oleh pajak dan pajak penghasilan $(\mathrm{PPh})$ berkontribusi sebesar $52,6 \%$ bagi penerimaan pajak negara (Damayanti, 2018). Sedangkan kontribusi dari pembayaran $\mathrm{PPh}$ final (PPh UMKM) terhadap keseluruhan pemasukan PPh baik yang dibayar WP OP dan WP Badan sebesar 2,2\% (www.pajak.go.id).

UMKM sebagai tulang punggung perekonomian selalu tumbuh setiap tahunnya. UMKM mendominasi perekonomian pada tahun 2019, yaitu sekitar $98,8 \%$ dari total unit usaha di Indonesia, sekitar 96,99\% dari total tenaga kerja di Indonesia dan sekitar 60,3\% dari total PDB Indonesia (www.depkop.go.id). Pertumbuhan UMKM tersebut dirasa belum sejalan dengan kepatuhan pajak pelaku usaha (Yusro dan Kiswanto, 2014). Berdasarkan fenomena ini untuk mengukur tingkat kepatuhan pajak dengan melihat tax gap nya. Menurut James dan Alley (2004) menyatakan tax gap adalah perbandingan jumlah pajak yang seharusnya terkumpul dengan seberapa besar jumlah pajak yang telah dibayarkan. Atau mengandung arti sebagai apa yang telah dilakukan oleh wajib pajak dengan apa yang tersurat dalam peraturan perundang-undangan perpajakan. Oleh sebab itu untuk selanjutnya peneliti akan menguji dan menganalisis pengaruh pemahaman peraturan perpajakan, kesadaran membayar pajak dan tingkat pendapatan UMKM terhadap kepatuhan wajib pajak UMKM.

\section{METODE}

Penelitian kuantitatif dengan model analisa yang digunakan adalah untuk menguji hipotesis apakah pemahaman peraturan perpajakan, kesadaran membayar pajak, dan tingkat pendapatan UMKM berpengaruh positif terhadap kepatuhan wajib pajak UMKM. Empat variabel yang digunakan dalam Operasional variabel diperlukan untuk instrumen kuesioner yaitu variabel bebasnya terdiri dari PPP (Pemahaman Peraturan Perpajakan), KMP (Kesadaran Membayar Pajak), TPU (Tingkat Pendapatan UMKM). Variabel terikatnya yaitu KPU (Kepatuhan Wajib Pajak UMKM). Skala likert skor 1 - 5 adalah yang digunakan untuk pengukuran variabel oleh peneliti. Dengan rincian poinnya yaitu Sangat Setuju $(S S)=5$, Setuju $(S)=4, \operatorname{Netral}(N)=3$, Tidak Setuju $(\mathrm{TS})=2$, Sangat Tidak Setuju $(\mathrm{STS})=1$. Penyebaran kuesioner didahului sebelumnya dengan melakukan pilot test. Pilot test ini dilakukan agar mengurangai tingkat masalah dalam menjawab pertanyaan dalam kuesioner yang diberikan kepada responden. Pada penelitian ini menggunakan data primer sebagai sumber utama datanya, yaitu datanya langsung dari pemilik UMKM. Populasi pada penelitian yaitu sebanyak 558 pelaku usaha yang menjadi binaan Dinas Koperasi dan UMKM Kota Surabaya.

Pengujian hipotesis menggunakan analisis regresi harus melalui syarat minimum pengujian agar linier tidak bias. Pada perhitungan statistik menggunakan persamaan regresi dirumuskan seperti berikut:

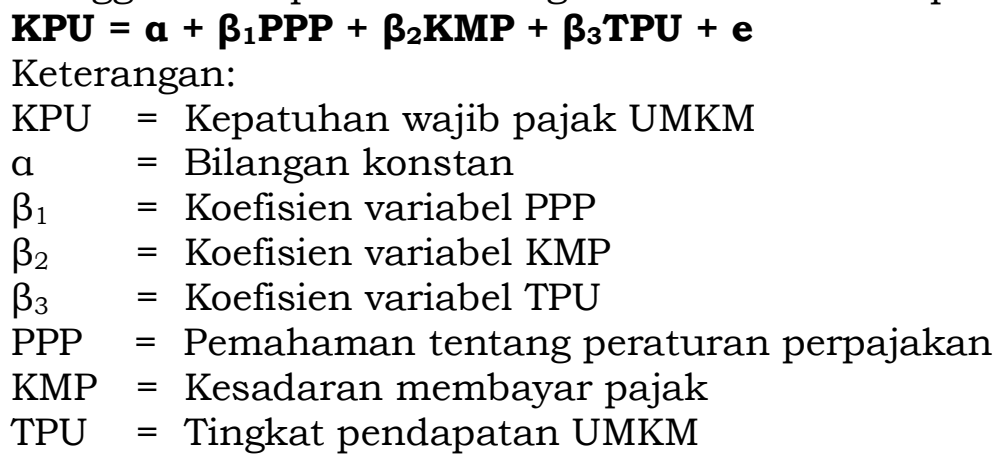


Pengambilan keputusannya adalah tingkat signifikansi $a<0,05$ pada tiap variabel bebas yang menentukan apakah menolak atau menerima hipotesis. Jika $<$ 0,05 maka menerima hipotesis jika $>0,05$ menolak hipotesis.

\section{HASIL DAN PEMBAHASAN}

Pengambilan data dilakukan dengan menyebar kuesioner secara langsung serta kuesioner melalui google form ke pemilik usaha yang terdaftar di Dinas Koperasi dan UMKM kota Surabaya. Terhitung sejak tanggal 22 Februari 2020 hingga 04 April 2020 kuesioner dibagikan dan di kembalikan. Adapun jumlah kuesioner yang disebar sebanyak 130 eksemplar dan yang kembali berjumlah 125 eksemplar. Yang layak diuji sebanyak 125 eksemplar. Berdasarkan kuesioner yang berhasil dihimpun sebanyak 125 eksemplar, maka dapat dikelompokan berdasarkan kategori profil responden (Tabel 1).

Tabel 1. Karakteristik Responden

\begin{tabular}{llcc}
\hline \multicolumn{1}{c}{ Kategori } & \multicolumn{1}{c}{ Keterangan } & Jumlah & Persentase \\
\hline 1.Jenis Kelamin & a. Laki-laki & 44 & $35,2 \%$ \\
& b. Perempuan & 81 & $64,8 \%$ \\
2.Bidang Usaha & a. Pedagang & 67 & $53,6 \%$ \\
& b. Pabrikan & 26 & $20,8 \%$ \\
& c. Jasa & 23 & $18,4 \%$ \\
& d. Lain-lain & 9 & $7,2 \%$ \\
3.Lama Usaha & a. < 2 tahun & 23 & $18,4 \%$ \\
& b. 2 - 4 tahun & 27 & $21,6 \%$ \\
& c. > 4 - 6 tahun & 33 & $26,4 \%$ \\
& d. > 6 - 8 tahun & 14 & $11,2 \%$ \\
4. Omzet Penjualan/tahun & e. > 8 tahun & 28 & $22,4 \%$ \\
& a. $\leq 300$ Juta & 45 & $36 \%$ \\
& b. > 300 Juta - 2,5 Miliar & 40 & $32 \%$ \\
& c. > 2,5 Miliar & 40 & $32 \%$ \\
\hline
\end{tabular}

Sumber: Data primer (diolah)

Berdasarkan demografi responden mayoritas responden adalah perempuan sebanyak 81 responden atau $64,8 \%$, bidang usaha responden mayoritas adalah pedagang sebanyak 67 responden atau 53,6\%, lama usaha responden diatas 4 sampai 6 tahun sebanyak 33 responden atau 26,4\%, omzet penjualan/tahun responden mayoritas adalah di bawah 300 juta/tahun sebanyak 45 responden atau 36\%.

Variabel pemahaman peraturan perpajakan memiliki instrumen dengan 12 butir pertanyaan dihasilkan mean merupakan nilai rata-rata sebesar 3,6166 , median merupakan nilai tengah sebesar 3,6700 yang artinya $50 \%$ nilai rata-rata jawaban kuesioner di atas 3,6700 dan $50 \%$ nilai rata-rata jawaban kuesioner di bawah 3,6700. Nilai rata-rata minimun sebesar 1,17 ini merupakan nilai rata-rata yang paling kecil, maximum sebesar 4,83 ini merupakan nilai rata-rata paling besar. Sedangkan mode sebesar 4,25 ini merupakan nilai rata-rata yang sering muncul.

Variabel kesadaran membayar pajak memiliki instrumen dengan 8 butir pertanyaan. Dengan nilai mean yang merupakan nilai rata-rata sebesar 4,0727, median yang merupakan nilai tengah sebesar 4,1300 yang artinya $50 \%$ jawaban kuesioner diatas 4,1300 dan $50 \%$ jawaban kuesioner di bawah 4,1300. Nilai rata-rata minimum sebesar 2,00 maximum sebesar 5,00. 
Sedangkan mode sebesar 4,00 ini merupakan nilai rata-rata yang paling sering muncul.

Variabel tingkat pendapatan UMKM memiliki instrumen dengan 5 butir pertanyaan. Dengan nilai mean yang merupakan nilai rata-rata sebesar 3,9040 , median yang merupakan nilai tengah sebesar 4,0000 yang artinya $50 \%$ jawaban kuesioner diatas 4,0000 dan 50\% jawaban kuesioner dibawah 4,0000. Nilai rata-rata minimun sebesar 2,00 dan maximum sebesar 5,00. Sedangkan mode sebesar 4,00 ini merupakan nilai rata-rata yang paling sering muncul.

Variabel kepatuhan wajib pajak UMKM memiliki instrumen dengan 11 butir pertanyaan. Dengan nilai mean yang merupakan nilai rata-rata sebesar 3,9460 , median yang merupakan nilai rata-rata tengah sebesar 4,0900 yang artinya $50 \%$ nilai rata-rata jawaban kuesioner diatas 4,0900 dan 50\% jawaban kuesioner dibawah 4,0900. Minimum sebesar 2,00 dan maximum sebesar 4,91. Sedangkan mode sebesar 4,45 ini merupakan nilai rata-rata yang sering muncul.

Uji validitas menunjukan semua hasil koefisien korelasi mempunyai nilai $>0,3$ dan nilai signifikan $<0,05$. Uji reliabilitas menunjukan nilai cronbach's alpha $>0,6$.

\subsection{Hasil Uji Asumsi Klasik}

Hasil normalitas diketahui bahwa nilai asym. Sig. 2 tailed $>0,05$ yaitu 0,066. Sehingga dapat disimpulkan semua data berdistribusi normal. Hasil uji multikolinieritas menunjukan bahwa semua variabel bebas mempunyai nilai tolerance $>0,1$ dan VIF $<10$ sehingga dapat disimpulkan bahwa tidak terjadi multikolinieritas. Uji heteroskedastisitas akan digunakan uji Park Glejser (Tabel 3).

Tabel 3. Hasil Uji Heteroskedastisitas

\begin{tabular}{ccccc}
\hline Model & df & F & Sig. & Keterangan \\
\hline Regression & 3 & 3,895 & 0,121 & Tidak Heteroskedastisitas \\
\hline Sumber: Data primer (diolah) & &
\end{tabular}

Diketahui bahwa korelasi pada signifikansi $0.121>0,05$ maka dapat ditarik kesimpulan bahwa masalah heteroskedastisitas tidak terjadi.

1. Uji Autokorelasi

Tabel 4. Hasil Uji Autokorelasi

\begin{tabular}{cccc}
\hline $\mathrm{dU}$ & Durbin-Watson & $4-\mathrm{dU}$ & Keterangan \\
1,757 & 2,172 & 2,243 & Tidak Autokorelasi \\
\hline
\end{tabular}

Sumber: Data primer yang diolah

Dengan uji Durbin-Watson diperoleh angka DW adalah 2,172 > 0,05, maka model dinyatakan tidak terjadi autokorelasi. Berdasarkan angka pada tabel $\mathrm{DW}$ nilai $\mathrm{dL}=1,659, \mathrm{dU}=1,757$, nilai $\mathrm{T}=125$ (responden), $\mathrm{k}=4$ (variabel). Nilai $(4-\mathrm{dU})=2,243$. Sehingga $\mathrm{dU}<\mathrm{d}<(4-\mathrm{dU})=1,757<2,172<2,243$ yang menunjukan DW berada antara dU $(1,757)$ dan nilai 4-dU $(2,243)$. Sehingga dapat dipastikan model regresi tidak terjadi autokorelasi.

\subsection{Hasil Uji Koefisien determinasi $\mathbf{R}^{2}$}

Tabel 5. Hasil Uji Determiniasi $\mathrm{R}^{2}$

\begin{tabular}{cccc}
\hline$R$ & $R^{2}$ & $\begin{array}{c}\text { Adjusted } \\
R^{2}\end{array}$ & $\begin{array}{c}\text { Std. Error Of } \\
\text { The Estimate }\end{array}$ \\
\hline 0,644 & 0,415 & 0,401 & 0,48066 \\
\hline
\end{tabular}




\section{Sumber: Data primer yang diolah}

Angka adjusted $\mathrm{R}^{2}$ menunjukan bahwa pemahaman peraturan perpajakan, kesadaran membayar pajak dan tingkat pendapatan UMKM mampu memberikan penjelasan terhadap kepatuhan wajib pajak sebesar $40,1 \%$, sedangkan variabel lain yang tidak digunakan pada penelitian ini menjelaskan sisanya. Nilai ini merupakan ukuran ketepatan dalam memprediksi data yang diteliti. $\mathrm{R}^{2}$ bisa menginterpretasikan sebagai persentase yang menjelaskan keberagaman nilai variabel dependennya Kolom standard error of the estimate menunjukan angka 0,48066 ini berarti banyaknya kesalahan dalam prediksi kepatuhan sebesar 0,48066. Semakin kecil angka SEE maka prediksi model regresi semakin tepat terhadap variabel bebas (Ghozali, 2011:97).

\subsection{Hasil Uji Koefisien Regresi (Uji F)}

\begin{tabular}{cccc}
\hline Model & df & F & Signifikan \\
\hline Regression & 3 & 28,636 & 0,000 \\
\hline
\end{tabular}

Sumber: Data primer yang diolah

Dari hasil analisa bahwa $\mathrm{F}$ hitung $=28,636$ dan signifikansi 0,000 . Nilai $\mathrm{F}$ tabel $(2,68)<F$ hitung $(28,636)$ dan signifikansi $F(0,000)<0,05$. Maka ditarik kesimpulan variabel bebas pada penelitian ini secara parsial berpengaruh signifikan terhadap variabel terikatnya. Maka dapat dikatakan bahwa model regresi layak diteliti untuk memprediksi pengaruh dari variabel bebas.

\subsection{Hasil Uji Regresi Linier Berganda}

Tabel 7. Hasil Uji Regresi Linier Berganda

\begin{tabular}{lcccc}
\hline \multirow{4}{*}{ variabel } & \multicolumn{4}{c}{$\begin{array}{c}\text { Unstandardized } \\
\text { Coefficients } \\
\text { Std. }\end{array}$} \\
& $\mathrm{B}$ & Error & $\mathrm{t}$ & Sig. \\
\hline (Constant) & 1,587 & 0,315 & 5,046 & 0,000 \\
PPP & 0,291 & 0,053 & 5,466 & 0,000 \\
KMP & 0,096 & 0,089 & 1,090 & 0,278 \\
TPU & 0,211 & 0,068 & 3,113 & 0,002 \\
\hline
\end{tabular}

Sumber: Data primer (diolah)

Model persamaan regresi dapat dituliskan sebagai berikut:

$$
\mathrm{KPU}=1,587+0,291 \mathrm{PPP}+0,096 \mathrm{KMP}+0,211 \mathrm{TPU}+\mathrm{e}
$$

Persamaan tersebut memiliki arti bahwa Constant memiliki nilai 1,587 memiliki interpretasi bahwa jika pemahaman peraturan perpajakan, kesadaran membayar pajak dan tingkat pendapatan UMKM terhadap kepatuhan wajib pajak UMKM bernilai nol, maka nilai kepatuhan pajak sebesar 1,587.

Variabel pemahaman peraturan perpajakan mempunyai nilai sebesar 0,291 maka berarti apabila variabel bebas yang lain nilainya tidak berubah atau tetap, maka dengan demikian setiap kenaikan sebesar $1 \%$ pemahaman peraturan perpajakan akan meningkatkan variabel kepatuhan pajak sebesar $29,1 \%$. 
Variabel kesadaran membayar pajak memiliki nilai koefisien sebesar 0,096 artinya terdapat hubungan yang lemah karena angka korelasi mendekati nol (0). Koefisien korelasi sebesar $0,278>0,05$ kondisi ini menunjukan bahwa tidak ada pengaruh, sehingga tidak memiliki hubungan searah terhadap kepatuhan pajak.

Variabel tingkat pendapatan UMKM memiliki nilai koefisien regresi sebesar 0,211 memiliki interpretasi bahwa jika variabel bebas yang lain nilainya tetap maka setiap kenaikan 1\% tingkat pendapatan maka akan meningkatkan kepatuhan pajak sebesar 21,1\%.

\subsection{Hasil Uji t}

\begin{tabular}{lccc}
\multicolumn{3}{c}{ Tabel 8. Hasil Uji t } \\
\hline Variabel & $\mathrm{t}$ & Signifikansi & Keterangan \\
\hline Constant & 5,046 & 0,000 & Berpengaruh \\
PPP & 5,466 & 0,000 & Berpengaruh \\
KMP & 1,090 & 0,278 & Tidak berpengaruh \\
TPU & 3,113 & 0,002 & Berpengaruh \\
\hline
\end{tabular}

Sumber: Data primer (diolah) ini:

Pengambilan keputusan dari hasil olah data pada tabel 8 seperti berikut

a. Variabel PPP (pemahaman peraturan perpajakan): $t$ hitung $(5,466)>t$ tabel $(1,657)$ dengan signifikansi $0,000<a(0,05)$, maka menerima hipotesis.

b. Variabel KMP (kesadaran membayar pajak): $t$ hitung $(1,090)<\mathrm{t}$ tabel $(1,657)$ dengan signifikansi $0,278>$ a $(0,05)$, maka hipotesis ditolak.

c. Variabel TPU (tingkat pendapatan UMKM): t hitung $(3,113)>t$ tabel $(1,657)$ dengan signifikansi $0,002<$ a 0,05, maka dengan demikian hipotesis diterima.

\subsection{Pengaruh Pemahaman Peraturan Perpajakan Terhadap Kepatuhan Wajib Pajak UMKM}

Hasil uji analisis data yang telah dilakukan maka hipotesis 1 diterima, karena variabel pemahaman peraturan perpajakan memiliki pengaruh terhadap kepatuhan wajib pajak UMKM. Hasil uji analisis memiliki arah yang positif pada persamaan regresi menunjukan bahwa semakin tinggi tingkat pemahaman peraturan perpajakan yang dimiliki oleh pemilik UMKM, maka semakin tinggi pula kepatuhan perpajakannya. Faktor pemahaman peraturan perpajakan sangatlah penting peranannya dalam melaksanakan kewajiban perpajakan. Sebagian masyarakat mendapatkan informasi terkait pajak melalui aparat pajak, media informasi, konsultan pajak, seminar atau pelatihan pajak, sosialisasi pajak dan lain sebagainya. Tentu akan berbeda bila wajib pajak yang tidak mengetahui informasi tentang peraturan perpajakan akan mengalami kesulitan untuk melaksanakan kewajiban perpajakannya. Wajib pajak yang mengetahui informasi tentang pajak akan menambah pengetahuan dan pemahamannya tentang perpajakan hal ini akan berpengaruh pada kepatuhannya disebabkan adanya motivasi dari wajib pajak. Bagi pemerintah pemahaman mengenai paraturan perpajakan merupakan potensi yang dapat meningkatkan kepatuhannya.

Pemahaman wajib pajak tentang peraturan perpajakan termasuk juga pemahaman mengenai hukum, dan tata cara perpajakan yang benar berdampak positif terhadap kepatuhan wajib pajak. Pemahaman yang baik 
dapat dengan mudah melakukan kewajiban perpajakannya. Sebab di Indonesia menggunakan sistem yang memberikan wewenang kepada wajib pajak untuk menghitung, membayar dan melaporkan sendiri pajak terutangnya (Nurmantu, 2010:68). Hasil uji analisis ini sejalan dengan penelitian yang dilakukan oleh Nugroho (2012), Imaniati (2016), Fahluzy dan Agustina (2014) serta Kalsum (2016) yang menyatakan bahwa pemahaman tentang peraturan perpajakan berpengaruh positif terhadap kepatuhan wajib pajak UMKM.

\subsection{Pengaruh Kesadaran Membayar Pajak Terhadap Kepatuhan Wajib Pajak UMKM}

Uji analisis data yang telah dilakukan maka hipotesis 2 ditolak, karena variabel kesadaran membayar pajak tidak berpengaruh terhadap kepatuhan wajib pajak UMKM. Hal ini dapat berarti kesadaran membayar pajak belum bisa meningkatkan kepatuhan pajaknya. Kesadaran perpajakan merupakan dorongan terhadap tindakan dan perasaan dari wajib pajak untuk melakukan kegiatan perpajakan tanpa paksaan (Rahayu, 2010:138). Pada kenyataannya hal ini tidak terjadi pada responden dalam penelitian ini. Karena pembayaran pajak UMKM dihitung berdasarkan omzet yang diperoleh wajib pajak, sehingga kesadaran bukanlah faktor yang mempengaruhi kepatuhannya. Apalagi jika usaha yang dijalankan belum lama dan belum menghasilkan laba. Hal ini dikhawatirkan akan terjadi penghindaran pajak atau penggelapan pajak dengan cara mengecilkan atau menurunkan omzet sehingga pajak yang dibayarkan tidak sesuai dengan seharusnya.

Selain itu alasan yang bisa diutarakan adalah kebutuhan hidup seharihari yang cukup tinggi dari pemilik UMKM, sehingga mengurangi kesadaran mereka untuk membayar pajak. Kurangnya motivasi dari wajib pajak dalam hal membayar pajak masih kurang, ada anggapan bahwa dengan membayar pajak wajib pajak tidak memperoleh manfaat langsung dari apa yang dia bayarkan sehingga timbul adanya pesimisme. Selain itu kurang efektifnya manfaat dari membayar pajak bagi mereka juga mengurangi kepatuhannya.

Berdasarkan hasil analisa tidak menunjukan arah yang berhubungan antara kesadaran membayar pajak dengan kepatuhan wajib pajak UMKM. Bisa jadi pembayaran pajak pemilik UMKM disebabkan adanya sanksi yang akan diterima jika tidak membayar pajak. Namun menurut peneliti sebelumnya yang dilakukan oleh Yusro dan Kiswanto (2014) serta penelitian yang dilakukan oleh Riyantono (2017) menyatakan hasil yang sama bahwa kesadaran membayar pajak tidak berpengaruh terhadap kepatuhan wajib pajak UMKM.

Pembayaran pajak terutang harus sesuai dengan peraturan perpajakan yang berlaku, karena jika hanya membayar tapi jumlah yang dibayarkan tidak sesuai dengan yang seharusnya, maka dapat merugikan negara. Begitu juga yang tercermin dari hasil penelitian, kesadaran membayar pajak pelaku usaha yang menjadi responden dalam penelitian ini cukup tinggi namun pembayaran PPh tersebut tidak sejalan dengan kepatuhan perpajakan yang seharusnya berlaku. Sistem pemungutan pajak yang berlaku di Indonesia yang mengharuskan wajib pajak menghitung hingga melaporkan kewajiban perpajakannya, dibutuhkan juga kedisiplinan (tax dicipline) dan kejujuran pelaku usaha sehingga akan tercipta hasrat untuk membayar atau tax mindness bagi wajib pajak yang sesuai dengan peraturan dan perundangundangan perpajakan yang berlaku. 


\subsection{Pengaruh Tingkat Pendapatan UMKM Terhadap Kepatuhan Wajib Pajak UMKM}

Hasil analisis yang telah dilakukan menunjukan hipotesis 3 diterima, berdasarkan hasil analisa bahwa tingkat pendapatan UMKM memiliki pengaruh positif terhadap kepatuhan wajib pajak UMKM. Hasil penelitian yang sama dilakukan juga oleh Yuliyanah (2018), Hardiningsih (2011), serta Carvallo dan Agusino (2016). Tingkat pendapatan adalah termasuk dalam faktor internal individu untuk memenuhi kewajiban perpajakannya. Pemilik usaha tidak menemui hambatan yang berarti jika besar kecilnya pajak yang dibayarkan masih dapat terpenuhi. Karena pemilik usaha akan menggunakan keuntungannya untuk keperluan sehari-hari terlebih dahulu sebelum membayar kewajiban pajaknya. Pendapatan usaha makin besar maka kepatuhan juga akan makin meningkat. Jika omzet usaha memberikan kemampuan untuk membayar pajak maka wajib pajak yang paham tentang peraturan perpajakan akan menjadi wajib pajak yang patuh. Responden pada penelitian ini menjelaskan bahwa mereka tidak akan bisa membayar pajak tiap bulan jika pendapatan usaha mereka tidak cukup untuk memenuhi kebutuhan hidup sehari-hari, khususnya pemilik usaha mikro. Dengan demikian jumlah pendapatan yang kecil untuk memenuhi kebutuhan hidup, maka tidak memungkinkan pemilik UMKM untuk membayar pajak. Oleh sebab itu tidak akan patuh pula sebagai wajib pajak. Omzet yang tinggi cenderung lebih mudah dan patuh untuk membayar pajak dibandingkan dengan usaha dengan omzet yang rendah. Kebanyakan dari responden pada penelitian ini akan menolak untuk membayar pajak jika omzet mereka masih rendah atau hanya cukup digunakan untuk keperluan sehari-hari.

\subsection{Hasil Uji Analisis Tambahan Usaha Mikro}

Pada uji analisis tambahan ini dapat diketahui seberapa besar atau dominannya pengaruh pemahaman peraturan perpajakan, kesadaran membayar pajak dan tingkat pendapatan UMKM terhadap kepatuhan wajib pajak UMKM sesuai omzet penjualan per tahunnya. Dari data kuesioner yang telah diterima 125 responden akan dibagi lagi sampel yang telah memilih untuk usaha mikro sebanyak 45 responden, 40 responden memilih usaha kecil dan usaha menengah sebanyak 40 responden. Setelah melalui uji validitas, uji reliabilitas dan uji asumsi klasik yang telah dilakukan

Tabel 9. Hasil Uji Determinasi $\mathrm{R}^{2}$ Usaha Mikro

\begin{tabular}{cccc}
\hline$R$ & $R^{2}$ & $\begin{array}{c}\text { Adjusted } \\
\mathbf{R}^{2}\end{array}$ & $\begin{array}{c}\text { Std. Error Of } \\
\text { The Estimate }\end{array}$ \\
\hline 0,344 & 0,119 & 0,054 & 0,64889 \\
\hline
\end{tabular}

Sumber: Data primer (diolah)

Nilai adjusted $\mathrm{R}^{2}$ untuk usaha mikro sebesar 0,054 atau 5,4\%. Hal ini menunjukan bahwa variabel pemahaman peraturan perpajakan, kesadaran membayar pajak dan tingkat pendapatan UMKM hanya 5,4\% yang dapat menjelaskan variabel kepatuhan wajib pajak UMKM.

Berdasarkan hasil uji regresi untuk responden usaha mikro, maka diperoleh hasil, yaitu: a) Pemahaman peraturan perpajakan (PPP): $t$ hitung $(2,096)>t$ tabel $(1,679)$ dengan sig. $0,042<$ a $(0,05)$. PPP berpengaruh positif terhadap kepatuhan wajib pajak UMKM; b) Kesadaran membayar pajak 
(KMP): t hitung $(-0,823)$ bernilai negatif dengan sig. 0,415 > a $(0,05)$. Berarti tidak ada pengaruh antara kesadaran membayar pajak terhadap kepatuhan wajib pajak UMKM; c) Tingkat pendapatan UMKM (TPU): $t$ hitung $(0,844)<\mathrm{t}$ tabel $(1,679)$ dengan sig. $0,404>$ a $(0,05)$. tingkat pendapatan UMKM tidak berpengaruh terhadap kepatuhan wajib pajak UMKM.

Tabel 10. Hasil Uji Regresi Usaha Mikro

\begin{tabular}{|c|c|c|c|c|}
\hline \multirow[b]{2}{*}{ Variabel } & \multicolumn{2}{|c|}{$\begin{array}{c}\text { Unstandardized } \\
\text { Coefficients }\end{array}$} & \multirow[b]{2}{*}{$\mathrm{t}$} & \multirow[b]{2}{*}{ Sig. } \\
\hline & B & $\begin{array}{l}\text { Std. } \\
\text { Error }\end{array}$ & & \\
\hline $\begin{array}{l}\text { (Constan } \\
\text { t) }\end{array}$ & 2,802 & 0,772 & 3,627 & 0,001 \\
\hline PPP & 0,283 & 0,135 & 2,096 & 0,042 \\
\hline KMP & $-0,156$ & 0,189 & $-0,823$ & 0,415 \\
\hline TPU & 0,129 & 0,153 & 0,844 & 0,404 \\
\hline
\end{tabular}

Sumber: Data primer (diolah)

\subsection{Hasil Uji Analisis Tambahan Usaha Kecil}

Tabel 11. Hasil Uji Determinasi $R^{2}$ Usaha Kecil

\begin{tabular}{cccc}
\hline $\mathrm{R}$ & $\mathrm{R}^{2}$ & $\begin{array}{c}\text { Adjusted } \\
\mathrm{R}^{2}\end{array}$ & $\begin{array}{c}\text { Std. Error Of } \\
\text { The Estimate }\end{array}$ \\
\hline 0,866 & 0,749 & 0,728 & 0,29854 \\
\hline
\end{tabular}

Sumber: Data primer (diolah)

Nilai adjusted $\mathrm{R}^{2}$ untuk usaha kecil sebesar 0,728 atau $72,8 \%$. Hal ini bermakna variabel pemahaman peraturan perpajakan, kesadaran membayar pajak dan tingkat pendapatan UMKM mampu menjelaskan terhadap kepatuhan wajib pajak UMKM sebesar $72,8 \%$.

Tabel 12. Hasil Uji regresi Usaha Kecil

\begin{tabular}{lcccc}
\hline & \multicolumn{4}{c}{$\begin{array}{c}\text { Unstandardized } \\
\text { Coefficients }\end{array}$} \\
\cline { 2 - 3 } Variabel & $\mathrm{B}$ & $\begin{array}{c}\text { Std. } \\
\text { Error }\end{array}$ & $\mathrm{t}$ & Sig. \\
\hline (Constant) & 0,684 & 0,355 & 1,927 & 0,062 \\
PPP & 0,226 & 0,070 & 3,225 & 0,003 \\
KMP & 0,376 & 0,099 & 3,800 & 0,001 \\
TPU & 0,217 & 0,089 & 2,437 & 0,020 \\
\hline
\end{tabular}

Sumber: Data primer (diolah)

Berdasarkan hasil uji regresi responden usaha kecil menginterpretasikan bahwa: a) Pemahaman peraturan perpajakan (PPP): t tabel $(1,684)<t$ hitung $(3,225)$ sig. $0,003<a(0,05)$. Pemahaman peraturan perpajakan berpengaruh positif terhadap kepatuhan wajib pajak UMKM; b) Kesadaran membayar pajak (KMP): $t$ hitung $(3,800)>t$ tabel $(1,684)$ sig. $0,001<a(0,05)$. KMP berpengaruh positif terhadap kepatuhan wajib pajak UMKM; c) Tingkat pendapatan UMKM (TPU): $t$ hitung $(2,437)>t$ tabel $(1,684)$ probabilitas 0,020 $<$ a $(0,05)$. Tingkat pendapatan UMKM berpengaruh positif terhadap KPU. 


\subsection{Hasil Uji Analisis Tambahan Usaha Menengah}

Tabel 13. Hasil Uji Determinasi $\mathrm{R}^{2}$ Usaha Menengah

\begin{tabular}{cccc}
\hline $\mathrm{R}$ & $\mathrm{R}^{2}$ & $\begin{array}{c}\text { Adjusted } \\
\mathrm{R}^{2}\end{array}$ & $\begin{array}{c}\text { Std. Error Of } \\
\text { The Estimate }\end{array}$ \\
\hline 0,747 & 0,559 & 0,522 & 0,30084
\end{tabular}

Sumber: Data primer (diolah)

Nilai adjusted $\mathrm{R}^{2}$ untuk usaha menegah sebesar 0,522 atau 52,2\%. Mempunyai makna bahwa pemahaman peraturan perpajakan, kesadaran membayar pajak dan tingkat pendapatan UMKM mampu memberikan penjelasan terhadap kepatuhan wajib pajak UMKM sebesar 52,2\%.

Berdasarkan hasil uji regresi pada responden usaha menengah dihasilkan: a) Pemahaman peraturan perpajakan (PPP): $t$ hitung $(2,313)>t$ tabel $(1,684)$ sig. $0,027<\mathrm{a}(0,05)$. Pemahaman peraturan perpajakan, kesadaran membayar pajak dan tingkat pendapatan UMKM berpengaruh positif terhadap kepatuhan wajib pajak UMKM; b) Kesadaran membayar pajak (KMP): $t$ hitung $(3,103)>t$ tabel $(1,684)$ sig. $0,004<a(0,05)$. KMP berpengaruh terhadap KPU; c) Tingkat pendapatan UMKM (TPU): $t$ hitung $(1,852)>\mathrm{t}$ tabel $(1,684)$ sig. $0,072>$ a $(0,05)$. Tingkat pendapatan UMKM berpengaruh terhadap KPU.

Tabel 14. Hasil Uji Regresi Usaha Menengah

\begin{tabular}{lcccc}
\hline Variabel & \multicolumn{3}{c}{$\begin{array}{c}\text { Unstandardized } \\
\text { Coefficients } \\
\end{array}$} & \multicolumn{5}{c}{$\begin{array}{c}\text { Std. } \\
\text { Error }\end{array}$} & t & Sig. \\
\hline (Constant) & 1.303 & 0,456 & 2,856 & 0,007 \\
PPP & 0,150 & 0,065 & 2,313 & 0,027 \\
KMP & 0,355 & 0,114 & 3,103 & 0,004 \\
TPU & 0,199 & 0,108 & 1,852 & 0,072 \\
\hline
\end{tabular}

Sumber: Data primer (diolah)

Dari hasil uji analisis tambahan dapat dijelaskan bahwa dari ketiga tingkat pendapatan usaha berdasarkan omzet per tahunnya ternyata responden yang tergolong pada usaha kecil memiliki kepatuhan pajak yang lebih dominan dibandingkan dengan yang lainnya. Hal ini berdasarkan dari nilai $\mathrm{R}^{2}$ yang lebih tinggi yaitu sebesar $72,8 \%$, kemudian disusul usaha menengah sebesar $52,2 \%$, sedangkan usaha mikro yang paling rendah yaitu sebesar 5,4\%. Berdasarkan hasil uji regresi tambahan juga dihasilkan responden kelompok usaha kecil lebih berpengaruh terhadap kepatuhan wajib pajak. Dari ketiga variabel independen yang digunakan untuk usaha kecil semua berpengaruh terhadap variabel dependen serta signifikansi alpha dari ketiga variabel independen usaha kecil dibawah 0,05. Hal ini dapat diartikan bahwa Responden Usaha kecil dapat menjelaskan sebesar 72,8\% hubungan yang sangat kuat dengan kepatuhan wajib pajak UMKM dan hubungan ini memiliki arah yang positif. Dengan demikian Responden pada penelitian ini yang masuk dalam kelompok usaha kecil memiliki pengaruh paling dominan dibandingkan dengan responden dari kelompok usaha mikro dan menengah. 
Dilihat dari karakteristik responden pada penelitian ini diketahui bahwa mayoritas responden merupakan pedagang dan lama usahanya berkisar antara 4 sampai 6 tahun. Wajib pajak untuk usaha mikro dan kecil didominasi oleh wajib pajak orang pribadi sedangkan usaha menengah ada yang merupakan wajib pajak badan. Dari sisi produktifitas usaha berdasarkan data responden rata-rata omzet usaha mikro berkisar $25 \%$ dari batas atas omzet Rp 300 juta, usaha kecil rata-rata omzet 65\% dari batas atas Rp 2,5 miliar dan usaha menengah rata-rata omzet 59\% dari batas atas omzet Rp 4,8 miliar. Hal ini menandakan bahwa usaha kecil paling produktif dan usaha mikro yang paling rendah. Sehingga dari sisi pendapatan yang diperoleh usaha kecil paling stabil.

\section{SIMPULAN}

Pemahaman peraturan perpajakan berpengaruh positif terhadap Kepatuhan Wajib Pajak UMKM. Artinya bahwa peningkatan pemahaman peraturan perpajakan dapat meningkatkan Kepatuhan Wajib Pajak UMKM. Kesadaran membayar pajak tidak berpengaruh terhadap kepatuhan wajib pajak UMKM. Artinya bahwa kesadaran membayar pajak tidak sejalan atau belum dapat memberikan pengaruhnya terhadap kepatuhan wajib pajak UMKM. Tingkat pendapatan UMKM berpengaruh positif terhadap kepatuhan wajib pajak UMKM. Artinya semakin tinggi pendapatan maka dapat mempengaruhi kepatuhan wajib pajak UMKM. Berdasarkan hasil uji analisis tambahan yang di kelompokan menurut omzet usaha (Mikro, Kecil dan Menengah) maka usaha kecil yang paling dominan terhadap kepatuhan wajib pajak UMKM. Keterbatasan penelitian yaitu terkait sampel yang diambil dan diteliti adalah hanya usaha yang terdaftar pada Dinas Koperasi dan UMKM Kota Surabaya. Oleh karena itu bagi peneliti selanjutnya yang ingin mengambil tema yang sama dapat menambah jumlah responden tidak hanya usaha yang terdaftar pada Dinas Koperasi dan UMKM saja, agar informasi yang dihasilkan lebih relevan pada kelompok usaha mikro, kecil dan menegah. Pemilihan variabel penelitian sebaiknya lebih teliti dan lakukan observasi atau pengamatan di lokasi pengambilan sampel yang akan diteliti supaya lebih paham kondisi dan situasi objek yang akan diteliti.

\section{REFERENSI}

Amran, A., 2018. Pengaruh Sanksi Perpajakan, Tingkat Pendapatan dan Kesadaran Wajib Pajak terhadap Kepatuhan Wajib Pajak Orang Pribadi. ATESTASI: Jurnal Ilmiah Akuntansi. 1(1), 1-15. https://doi.org/10.33096/atestasi.v1i1.5

Arum, \& Zulaikha, 2012. Pengaruh Kesadaran Wajib Pajak, Pelayanan Fiskus, dan Sanksi Pajak terhadap Kepatuhan Wajib Pajak Orang Pribadi yang Melakukan Kegiatan Usaha dan Pekerjaan Bebas (Studi di Wilayah KPP Pratama Cilacap). Semarang: Universitas Diponegoro

Damayanti, F., \& Susanto, T., 2015. Pengaruh Komite Audit, Kualitas Audit, Kepemilikan Institusional, Risiko Perusahaan dan Return On Assets Terhadap Tax Avoidance. Jurnal Bisnis dan Manajemen, 5(2), 187-206

Damayanti, T. W., \& Martono, S., 2018. Taxpayer Compliance, Trust, and Power. Jurnal Keuangan Dan Perbankan. 22(2), 231-239. https://doi.org/10.26905/jkdp.v22i2.1580

Fuadi, Arabella Oentari, \& Yenni Mangoting, 2013. Pengaruh Kualitas Pelayanan Petugas Pajak, Sanksi Perpajakan, dan Biaya Kepatuhan Pajak Terhadap Kepatuhan Wajib Pajak. Surabaya: Universitas Kristen Petra 
Gautama, 2014. Analisis Faktor-faktor yang Mempengaruhi Kepatuhan Pajak Orang Pribadi Dalam membayar Pajak. Jurnal Ilmu dan Riset Akuntansi. Vol.3, No.12, Pp. 15-19

Ghozali, Imam. 2011. Aplikasi Analisis Multivariate dengan Program IBM SPSS 19. Semarang: Badan Penerbit Universitas Diponegoro

Hardiningsih, \& Pancawati, 2011. Faktor-faktor yang Mempengaruhi Kemauan Membayar Pajak, Jurnal Dinamika Keuangan \& Perbankan, Vol. 3, No.1:126-142. Semarang: Universitas Stikubank

James, \& Alley, 2004. Tax Compliance, Self Assessment and Tax Administration, Journal of Finance and Management in Public Services. Vol.2, No.2, Pp. 27-42

Kalsum, Ummi, 2016. Pengaruh pemahaman Perpajakan dan Kesadaran Wajib Pajak Terhadap Kepatuhan Wajib Pajak UMKM di Kota Pekanbaru, Riau: Universitas Riau

Lazuardini, E. R., Susyanti, H. J., \& Priyono, A. A., 2018. Pengaruh Pemahaman Peraturan Perpajakan, Tarif Pajak Dan Sanksi Pajak Terhadap Kepatuhan Wajib Pajak UMKM. E - Jurnal Riset Manajemen PRODI MANAJEMEN, 7(1), 25-34.

Mahfud; Muhammad Arfan, \& Syukriy Abdullah, 2017. Pengaruh Pemahaman Peraturan Perpajakan, Kesadaran Membayar Pajak, dan Kualitas Pelayanan Perpajakan Terhadap Kepatuhan Wajib Pajak Badan (Studi Empiris Pada Koperasi di Kota Banda Aceh). Magister Akuntansi Pascasarjana Universitas Syiah Kuala 9, 1-9.

Mustofa, Fauzi Achmad; Kertahadi, \& Mirza Maulinarhadi, 2016. Pengaruh Pemahaman Peraturan Perpajakan, Tarif Pajak dan Asas keadilan Terhadap Kepatuhan Wajib Pajak. Fakultas Ilmu Administrasi Universitas Brawijaya, Malang

Nugroho, R. A., 2012. Faktor-Faktor Yang Mempengaruhi Kemauan Untuk Membayar Pajak Dengan Kesadaran Membayar Pajak Sebagai Variabel Intervening (Studi Kasus Wajib Pajak Orang Pribadi Yang Melakukan Pekerjaan Bebas Yang Terdaftar Di KPP Pratama Semarang Tengah Satu). 1(1), 150-160.

Nurmantu, Safri, 2010. Pengantar Perpajakan. Jakarta: Kelompok Yayasan Obor

Oladipupo, A.O., \& Obazee, U., 2016. Tax Knowledge, Penalties and Tax Compliance in Small and Medium Scale Enterprises in Nigeria, iBusiness, Vol.2, No.1, Pp.1-9

Putri, E., Purbasari, H., Handayani, M. T., \& Ulynnuha, O. I., 2018. Analisis Faktor-Faktor Yang Berpengaruh Terhadap Kesadaran Kewajiban Perpajakan Pada Sektor Usaha Kecil Dan Menengah (UKM). Riset Akuntansi Dan Keuangan Indonesia, 3(1), 80. https://doi.org/10.23917/reaksi.v3i1.5733

Rahayu, Siti Kurnia, 2010. Perpajakan Indonesia: Konsep dan Aspek Formal. Yogyakarta: Graha Ilmu.

Sasmita, Sentya N. Arum, 2015. Pengaruh Pemahaman Wajib Pajak, Pelayanan Fiskus, Kesadaran Wajib Pajak, dan Sanksi Perpajakan Terhadap Kepatuhan Wajib Pajak Pemilik Usaha Kecil Menengah dalam Pelaporan Kewajiban Perpajakan di Semarang, Semarang: Jurnal Akuntansi Universitas Pandanaran

Sekaran, Uma, 2009. Metode Penelitian untuk Bisnis. Jakarta: Salemba Empat Serim, N., Inam, B., \& Murat, D., 2014. Factors Affecting Tax Compliance of Taxpayers: The Role of Tax Officer The Case of Istanbul and Canakkale, Business and Economics Research Journal, Vol.5, No.2, Pp. 19-31 
Suandy, Erly, 2011. Hukum Pajak, Edisi 5, Salemba Empat, Jakarta.

Sugiyono, 2010. Metode Penelitian Bisnis, Bandung: Alfabet

Widayati, \& Nurlis, 2010. Faktor-Faktor Yang Mempengaruhi Kemauan Membayar Pajak Wajib Pajak Orang Pribadi Yang Melakukan Pekerjaan Bebas (Studi kasus pada KPP Pratama Gambir Tiga). Simposium Nasional Akuntansi XIII

Yuliyanah, Putri Rizqiyah; Dien Noviany, R., \& Baihaqi Fanani, 2018. Pengaruh Omzet Penghasilan, Tarif Pajak Serta Self Assessment System Terhadap Kepatuhan Wajib Pajak UMKM di Kota Tegal. Universitas Pancasakti, Tegal

Yusro, Heny Wachidatul, \& Kiswanto, 2014. Pengaruh Tarif Pajak, Mekanisme Pembayaran Pajak Dan Kesadaran Membayar Pajak Terhadap Kepatuhan Wajib Pajak UMKM Di Kabupen Jepara. Accounting Analysis Journal, 3(4), 429-436. https://doi.org/10.15294/aaj.v3i4.4201

Zain, Mohammad, 2007. Manajemen Perpajakan. Jakarta: Salemba Empat 